\title{
EFFECT OF ULTRASOUND ON S. EPIDERMIDIS MUSEUM CULTURE
}

D0I: 10.36740/WLek202004131

\author{
Yuliia V. Sidash, Olha N. Boychenko, Ivan Yu. Popovych, Andrii V. Zaytsev \\ UKRAINIAN MEDICAL STOMATOLOGICAL ACADEMY, POLTAVA, UKRAINE
}

\begin{abstract}
The aim of the present research project was to study the effect of ultrasonic waves on the S. epidermidis ATCC 14990 museum culture.

Materials and methods: A bibliosemantic method - for analyzing previous research based on scientific literature, electronic resources, empirical methods of scientific research (observation, comparison, measurement, experiment) - to study the effect of ultrasound on the strain of S. epidermidis ATCC 14990.

Results: A study showed that when exposed to ultrasound for four and a half minutes on a culture of microorganisms $S$. epidermidis in glass tubes, the number of viable cells in the suspension decreases.

Conclusions: The influence of ultrasound on the culture of S. epidermidis, studied in the work, showed that the selected and used parameters of ultrasound treatment cause destructive changes in microorganisms. These changes are not fatal for the entire bacterial culture used in the study, but they have a reliable antimicrobial effect.
\end{abstract}

KEY WORDS: ultrasound, microorganisms, medicine

Wiad Lek. 2020;73(4):786-788

\section{INTRODUCTION}

The microflora of plaque plays an important role both in physiological processes and in the pathology onset. It is associated with dental caries and periodontal inflammatory diseases. According to modern concepts, microorganisms are the cause of these diseases $[1,2,3]$. However, this view is not common to everyone. Among other things, it changes with time [4].

The functionality of the microflora causes ambivalent attitude to it within the medical community in terms of their strategies and tactics in the approaches to the odontopoiesis and periodontal pathologies treatment [5]. The current strategy for the elimination of microorganisms and further infection suggests antimicrobial therapy, which includes the use of selective drug products, as well as thorough mechanical manual treatment of both the focal point and the tools. Along with the traditional methods, alternatives are used: the use of ultrasound, ozone, laser and other types of effects on the microbial factor $[6,7,8]$.

Concerning the ultrasonic effect on microorganisms, it is ambiguous. Under its action, cellular associations and cells themselves are destructed [9]. However, the effect of ultrasound can also improve the functional abilities of microorganisms [10]. Such a contradiction contributes to the further study of the processes associated with the ultrasonic treatment of microorganisms.

\section{THE AIM}

The aim of the present research project was to study the effect of ultrasonic waves on the S. epidermidis ATCC 14990 museum culture.

\section{MATERIALS AND METHODS}

To perform the study, the daily culture of the S. epidermidis ATCC 14990 museum strain was used. A bacterial suspension was prepared in sterile normal saline solution up to $10^{3}$ colony-forming units per milliliter ( $\mathrm{CFU} / \mathrm{ml}$ ).

The amount of $1 \mathrm{ml}$ bacterial suspension was introduced into glass tubes, to which piezoelectric ceramic radiators were fixed with silicone glue. After the ultrasound treatment of microorganisms, $0.1 \mathrm{ml}$ of the suspension was plated on meat-peptone agar and, after incubation, the number of CFU / $\mathrm{ml}$ was counted.

To perform the study, an ultrasonic generator of low power with a frequency of 30 kilohertz was used. Piezoelectric ceramic radiators were connected to the generator output. The resonance frequency of the emitters was below $30 \mathrm{kHz}$, so they worked on harmonics. Emitters of different diameters were used: a piezoceramic emitter with the $27 \mathrm{~mm}$ diameter, a piezoceramic emitter with the $15 \mathrm{~mm}$ diameter, a piezoceramic emitter with the $12 \mathrm{~mm}$ diameter. The effect on the microorganisms culture was carried out for four and a half minutes.

\section{RESULTS AND DISCUSSION}

The performed study showed that the action of ultrasound during four and a half minutes on the S. epidermidis microorganisms culture suspension, located in glass test tubes, reduces the number of viable cells in suspension.

The results of $S$. epidermidis suspension inoculation, subjected to the action of ultrasound using different piezoelectric ceramic emitters, are presented in the table I.

As a result of the study performed, it was found that the ultrasound action caused a change in the number of 
Table I. Results of the S. epidermidis growth before and after the ultrasound impact (CFU / $\mathrm{ml}$ )

\begin{tabular}{|c|c|c|c|c|c|}
\hline Culture & $\begin{array}{l}\text { Stat. } \\
\text { index }\end{array}$ & $\begin{array}{l}\text { Before impact } \\
\qquad(n=10)\end{array}$ & $\begin{array}{c}\text { Emitter } \\
27 \text { MM } \\
(n=10)\end{array}$ & $\begin{array}{c}\text { Emitter } \\
15 \text { мм } \\
(n=10)\end{array}$ & $\begin{array}{c}\text { Emitter } \\
12 \mathrm{Mm} \\
(\mathrm{n}=10)\end{array}$ \\
\hline \multirow{3}{*}{ S.epidermidis } & $M$ & 30.7 & 26.1 & 29.4 & 29.7 \\
\hline & $\pm M$ & 1.02 & 1.16 & 0.70 & 0.78 \\
\hline & $\mathrm{p}$ & & 0.0009 & 0.033 & 0.073 \\
\hline
\end{tabular}

$\mathrm{CFU} / \mathrm{ml}$. If before the action of ultrasound the number of CFU / $\mathrm{ml}$ was $30.7 \pm 1.02$, then the use of a piezoelectric emitter with a diameter of $27 \mathrm{~mm}$ caused the reduction in the number of colonies obtained up to $26.1 \pm 1.16$ ( $\mathrm{p}=$ 0.0009 ), a piezoelectric emitter with a diameter of $15 \mathrm{~mm}$ - reduction in the number of colonies up to $29.4 \pm 0.70$ $(\mathrm{p}=0.033)$, a piezoelectric emitter with a diameter of 12 $\mathrm{mm}$ - reduction in the number of colonies up to $29.7 \pm$ $0.78(\mathrm{p}=0.073)$.

The obtained results are explained by the occurrence of sound chemical reactions in microorganisms under the impact of ultrasound. Ultrasonic waves caused a disorder of the cell membranes properties, changes in the concentration of substances dissolved in the cytoplasm. The cavitation phenomenon, which occurs under the influence of ultrasound in microorganisms, causes a disorder of the microorganisms integrity and their death [11]. Considering the fact that the oral cavity is populated with a large number of microorganisms that are part of the dental plaque, violate oral hygiene, contribute to the development of caries and inflammatory periodontal diseases [2, 3 ], the identified antibacterial effect of ultrasonic waves is important for dentistry. Along with the use of antiseptics $[12,13]$, ultrasound effects on the oral cavity microflora are considered promising in the treatment of caries and inflammatory diseases of periodontal tissues.

However, the fact that reduction in the population of microorganisms in our research was not total, leads to contemplations of another kind. The purpose of almost all experimental studies is to find such a set of input controlled variables in which the target function acquires an extreme value as a result of the minimum number of experiments at the lowest cost and means. Our study showed the dependence of the bacteria number on the area of the ultrasound emitting antenna. It follows that bacterial colonies can be controlled by changing the parameters of ultrasonic radiation. This dependence can be put into formulas for further research, which, quite likely, will concern not only individual cultures, but also their communities - bacterial biotopes.

\section{CONCLUSION}

The effect of ultrasound on S. epidermidis culture studied in this work showed that the selected and used parameters of ultrasound exposure introduce destructive changes into microorganisms. These changes are not lethal for the entire bacterial culture used in the study, but they produce a significant antimicrobial action with a controlling effect.

\section{REFERENCES}

1. Boychenko 0.N., Kotelevskaya N.V., Nykolyshyn A.K., Zaytsev A.V. Morfofunktsionalnaya harakteristika nazubnogo naleta [Morphofunctional characteristic of dental plaque]. Visnyk problem biolohiyi i medytsyny. 2017; 4: 2(134): 9-15. (in Russian)

2. Petrushanko T.A., Chereda V.V., Loban' G.A. The relationship between colonization resistance of the oral cavity and individual -typological characteristics of personality: dental aspects. Wiad Lek. 2017; 70(4):754-757.

3. Faustova M.O., Ananieva M.M., Basarab Y.0., et al. Bacterial factors of cariogenicity (literature review). Wiad Lek. 2018; 71(2 pt 2):378-382. Review.

4. Drannyk H.N. Sovremennyie dannyie o preimuschestvah yogurta [Current evidence on the benefits of yogurt]. K.; 2014; 39. (in Russian)

5. Petrushanko T.O., Chereda V.V., Loban H.A. Yakisnyisklad mikrobiotsenozu rota osib molodoho viku z riznoiu intensyvnistiu kariiesu [Qualitative composition of the microbiocenosis of the mouth of young people with different caries intensity]. Svit medytsyny ta biolohiyi. 2013;36:57-59. (in Ukrainian)

6. Bubliy T.D., Chechotina S.Yu. Doslidzhennia bolovoi chutlyvosti pry provedenni skelenhu [Study of pain sensitivity during skelenging]. Materialy Vseukrayinskoyi naukovo-praktychnoyi konferentsiyi. Medychna nauka v praktyku okhorony zdorovya. Poltava. 21 lystopada 2014; 9. (in Ukrainian)

7. Zaytsev A.V. Likuvannia neuskladnenoho kariiesu u khvorykh starshykh vikovykh hrup z obmezhenoiu rukhomistiu oporno-rukhovoho aparatu z vykorystanniam atravmatychnoi vidnovnoi tekhniky [Treatment of uncomplicated caries in patients of older age groups with limited mobility of the musculoskeletal system using atraumatic restorative technique]: dys. na zdobuttya stupenya kand. med nauk: spets. 14.01.22 «Stomatolohiya». Poltava. 2012; 140. (in Ukrainian)

8. Ivanytskyi I.0., Hasyuk N.V., Popovych I.Yu. Porivnialna kharakterystyka morfo metrychnykh pokaznykiv i histostruktury tverdykh tkanyn zubiv za umov ultrazvukovoho ta klasychnoho odontopreparuvannia [Comparative characteristics of morphometric indices and histostructure of hard tissue of teeth under the conditions of ultrasonic and classical odontopreparation]. Aktualni problemy suchasnoyi medytsyny. Visnyk Ukrayinskoyi medychnoyi stomatolohichnoyi akademiyi. 2013; 13, 2 (42): 202-205. (in Ukrainian)

9. Inguglia E.S., Tiwari B.K., Kerry J.P., Burgess C.M. Effects of high intensity ultrasound on the inactivation profiles of Escherichia coli K12 and Listeria innocua with salt and salt replacers. Ultrason Sonochem. 2018 Nov; 48:492-498.

10. Li J., Ma L., Liao X., et al. Ultrasound-Induced Escherichia coli 0157:H7 Cell Death Exhibits Physical Disruption and Biochemical Apoptosis. Front Microbiol. 2018 0ct 16; 9:2486.

11. Antusheva T.Y. Nekotoryie osobennosti vliyaniya ultrazvuka na mikroorganizmyi [Some features of the effect of ultrasound on microorganisms]. Zhyvyie y biokosnyie sistemy; 2013.(4):s11-15. (in Russian) 
12. Perederiy N.A. Funkcyonalnost mikrobioty pri patologii [Microbiota functionality in pathology]. Svit medytsyny ta biolohiyi. 2017; 61: 177-181. (in Russian)

13. Paliy H.K., Nazarchuk 0.A., Faustova M.0., et al. Doslidzhennia efektyvnosti antymikrobnykh preparativ u patsiientiv iz zapalnimy zakhvoriuvanniamy porozhnyny rota [Investigation of the effectiveness of antimicrobials in patients with inflammatory diseases of the oral cavity]. Visnyk problem biolohiyi i medytsyny. 2016; 130: 220-225. (in Ukrainian)

The work is a fragment of the research project "Development of new pre-diagnostics, treatment and prevention of dental diseases in patients with the musculoskeletal system's disorders" (state registration number 0112U004469).

\section{ORCID and contributionship:}

Yuliia V. Sidash - 0000-0001-8955-754X $X^{A, C}$

Olha N. Boychenko - 0000-0003-1079-5719 D,F

Ivan Yu. Popovych - 0000-0003-1720-095X ${ }^{E}$

Andrii V. Zaytsev - 0000-0003-3123-5681 ${ }^{B}$

\section{Conflicts of interest:}

Authors declare no conflict of interest.

\section{CORRESPONDING AUTHOR}

\section{Yuliia V. Sidash}

Ukrainian Medical Stomatological Academy

Shevchenka st, 23, 36011, Poltava, Ukraine

tel: +380509809865

e-mail: u.v.sidash@ukr.net

Received: 10.06.2019

Accepted: 18.02 .2020

A - Work concept and design, B - Data collection and analysis, C - Responsibility for statistical analysis,

D-Writing the article, $\mathbf{E}$-Critical review, $\mathbf{F}$ - Final approval of the article 